\title{
The radical right and the end of Swedish exceptionalism
}

\author{
Jens Rydgren ${ }^{1} \cdot$ Sara van der Meiden ${ }^{1}$
}

Published online: 2 May 2018

(C) The Author(s) 2018

\begin{abstract}
Fifteen years ago, Rydgren (Scand Polit Stud 25(1):27-56, 2002) asked why no electorally successful radical right-wing party had yet emerged in Sweden. In this respect, Sweden was a negative case. Rydgren posited four main explanations: (1) social class mattered more in Sweden than elsewhere. Working-class voters identified strongly with their social class and with the Social Democratic party, making them largely unavailable to radical right-wing mobilization; (2) socioeconomic issues still structured most politics in Sweden, and issues belonging to the sociocultural dimension-most importantly immigration-were of low salience for voters; (3) voters still perceived clear policy alternatives across the left-right divide; and (4) the leading radical right-wing alternative, the Sweden Democrats, was perceived as being too extreme. Since 2010, however, Sweden can no longer be considered a negative case, and in this article, we argue that in order to understand the rise and growth of the Sweden Democrats, we should focus on changes in the factors enumerated above.
\end{abstract}

Keywords Class voting $\cdot$ Radical right $\cdot$ Realignment $\cdot$ Sweden

Jens Rydgren

jens.rydgren@sociology.su.se

Sara van der Meiden

sara.vandermeiden@sociology.su.se

1 Department of Sociology, Stockholm University, 10691 Stockholm, Sweden 


\section{Introduction $^{1}$}

Over the past three decades, we have witnessed a resurgence of radical right-wing parties in Europe. These parties share an emphasis on ethnonationalism rooted in myths about the past, and their programs are directed toward making the nation more ethnically homogeneous. They also tend to be populists in that they accuse elites of favoring internationalism and cosmopolitanism over the nation, and of putting their own narrow self-interests and various special interests ahead of the interests of the people. Hence, the core message of radical right-wing parties is a mixture of ethnic nationalism-or nativism - and antiestablishment populism (Rydgren 2007, 2018; Mudde 2007); their main rallying issue, at least in Western Europe, has been opposition to immigration.

The electoral success of radical right-wing parties has varied substantially from country to country and over time. Sweden was until a few years ago considered a deviant case, which unlike its Scandinavian neighbors Denmark and Norway lacked a radical right-wing party in parliament. With the partial exception of the 1991 election, when the newly formed New Democracy garnered $6.7 \%$ of the vote, no Swedish radical right-wing party had come close to winning a parliamentary seat until the 2010 election. In the 2002 election, the Sweden Democrats received only $1.4 \%$ of the votes, which more than doubled to $2.9 \%$ in the 2006 election. In the 2010 election, the Sweden Democrats received $5.7 \%$ of the vote and won seats in the national parliament, and in the 2014 election the party received $12.9 \%$, which made it clear that Sweden is no longer exceptional in not having had an electorally successful radical right-wing party. In this paper, we seek to explain this transition and the changes in Swedish politics that may explain the rapid growth of the Sweden Democrats.

Fifteen years ago, Rydgren (2002) asked why Sweden was exceptional in that no electorally successful radical right-wing party had emerged. Rydgren posited four main explanations in the paper: (1) social class still mattered more in Sweden than elsewhere. Working-class voters identified rather strongly with their social class and with the Social Democratic party, making them largely unavailable to radical right-wing mobilization; (2) partly as a result of this, socioeconomic issues still structured most politics in Sweden, and issues belonging to the sociocultural dimension-most importantly immigration-were of low salience to the voters; (3) there was a relatively low degree of convergence between the major mainstream parties, and voters still perceived clear policy alternatives across the left-right divide; and (4) the leading radical right-wing alternative, the Sweden Democrats, was perceived as being too extreme.

In this paper, we will examine the four factors listed above in order to explain why Sweden is no longer an exceptional, or deviant, case. We will argue that in order to understand the rise and growth of the Sweden Democrats we should focus on (1) the decline of class politics in Sweden; (2) the growing salience of

\footnotetext{
1 This is a shorter version of a working paper (Rydgren \& van der Meiden 2016). Because of space limitations, we have left out e.g., discussions on the role of political distrust.
} 
sociocultural politics, and in particular the politicization of the immigration issue; (3) the increased convergence caused by a double move toward the center by the Social Democratic party and the Conservative party, leaving voters confused about policy alternatives; and (4) the process by which the Sweden Democrats have tried to distance itself from its neo-fascist past and erect a more respectable façade.

\section{Dealignment and realignment}

Contemporary Western European democracies are characterized by two major cleavage dimensions: the perceived economic rift that pits workers against capital and concerns the degree of state involvement in the economy, and sociocultural conflict that revolves around issues such as immigration, law and order, abortion, among others. The relative strength of these two sources of tension influences radical rightwing parties' chances for successful electoral mobilization. As some of these issues lose in salience, frames connected to them become less effective for people's interpretation of the world. As Kriesi et al. (1995: 4) have stressed, old cleavages may provide "a shield against the framing attempts of rising collective actors."

As will be further discussed below, one of the reasons why Sweden lacked an electorally strong radical right-wing party for as long as it did was the lingering strength of the socioeconomic cleavage dimension, manifested by the hegemonic position of the Social Democratic party, which worked as a shield against political actors trying to mobilize on (the authoritarian side) of the sociocultural dimension (Rydgren 2002, 2010). However, this situation has gradually changed over the past 10-15 years, opening up a space for radical right-wing mobilization.

\section{Decline in class voting}

Compared to its Nordic neighbors, the realignment process in Sweden was delayed. Socioeconomic politics still dominated the agenda and voters prioritized these over sociocultural political issues (see Table 1 below). Although class voting declined slowly in Sweden, it remained fairly high throughout the 1990s and early 2000s, especially among the working classes. However, as we will see below, this has recently begun to change.

Table 1 Attitudes toward refugees and immigrants, 1993-2009

\begin{tabular}{lllllll}
\hline Percentage who agree that: & 1993 & 1997 & 1999 & 2004 & 2007 & 2009 \\
\hline $\begin{array}{l}\text { There are too many refu- } \\
\text { gees living in Sweden }\end{array}$ & 52 & 48 & 40 & 42 & 39 & 36 \\
$\begin{array}{l}\text { They would not like to } \\
\text { see a relative marry an } \\
\text { immigrant }\end{array}$ & 25 & 18 & 17 & 15 & 14 & 12 \\
\hline
\end{tabular}


Class voting usually refers to when people belonging to the same social class vote, statistically, in the same way. This is assumed to be a consequence of their common interests, which are based on their shared socioeconomic position (e.g., Nieuwbeerta and De Graaf 1999). The relationship between social class and party choice has always been stronger in Sweden than in most other Western countries, since the Social Democratic hold on the working class has traditionally been strong (Oskarson and Demker 2013). As long as the traditional class-based cleavage dominated, there was little room for competing cleavage dimensions. Over the past decades class voting has decreased all over Western Europe, and in the North-Western countries, this process has mainly been driven by weakened alignment between social democratic parties and the working class (see, e.g., Clark and Lipset 2001; Oskarson 2005).

The decline of class voting has previously been explained with reference to major societal changes (e.g., modernization and globalization, and increased educational levels) as well as to changes in people's value structures (e.g., Betz 1994; Evans 1999). The overall left-right polarization in the party system also seems to affect class voting (Jansen et al. 2012), meaning that ideological convergence between mainstream parties may decrease class voting as well (Evans and Tilley 2012a, b). As discussed further below, when social democratic parties move toward the center in order to win middle-class voters, the effect may be weakened alignments with working-class voters. In addition, the position of social democratic parties on sociocultural issues influences class voting: as social democratic parties increasingly tried to mobilize based on left-liberal sociocultural policies that were predominantly embraced by the new middle classes, they may have alienated some working-class voters who on average share more traditional and authoritarian values (Kitschelt 1995, 2012). In any case, a decrease in left-right distinctions leaves room for other cleavage dimensions to be politicized.

There is ample evidence that class voting has decreased in Sweden, and that this trend intensified over the past decade. In the latest election, in 2014, the Alford index ${ }^{2}$ decreased to its lowest value yet: 23, compared to 51 in 1956 (Oscarsson 2016). Another example of eroding class loyalties is the weakened relationship between trade union membership and party choice. The support for the Social Democrats from members of the Swedish Trade Union Confederation (LO) decreased from $80 \%$ in 1956 to 52\% in 2010 (Oscarsson and Holmberg 2013), and in the official Statistics Sweden poll in the fall of 2015 it was down to $42 \%$ (SCB 2015). At the same time, support for the Sweden Democrats increased dramatically within this group. In 2015, 24\% of unionized working-class voters supported the party, making the Sweden Democrats the second most popular party among this voter category (SCB 2015).

At the same time, trade union membership has declined in Sweden since the beginning of 1990s. In 2015, $71 \%$ of all employees were members of a trade union, and the share among workers was $65 \%$. Twenty years earlier $88 \%$ of all workers

\footnotetext{
2 Alford's index is the difference between the share of socialist voters in the working class and the share of the socialist voters in the middle class.
} 


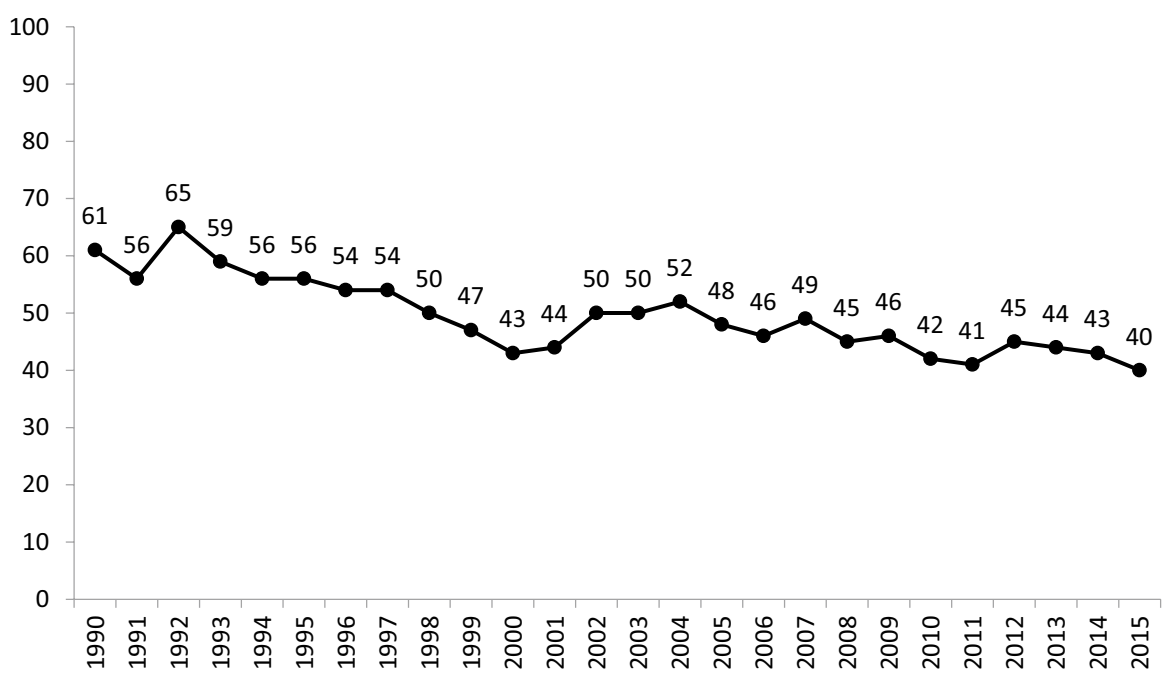

Fig. 1 Attitudes toward refugees and immigrants, 1990-2015 (percent). Source: Demker and Sandberg (2014), Demker (2015), Demker and van der Meiden (2016)

were union members, so the decline has been rather dramatic (Larsson 2015). This is important, since we know that the support for radical right-wing parties tends to be higher among non-unionized workers than among unionized working-class voters (Sannerstedt 2015). Also more generally, the decreasing ability of trade unions to integrate workers into the left-leaning electorate-since these organizations have lost some of their socializing role-favors radical right-wing parties (Andersen and Bjørklund 1990: 214; Oesch 2008).

In sum, the decline of class-based voting is highly significant since we know from previous studies that working-class voters are among those most susceptible to radical right-wing-type parties (see e.g., Oesch 2008; Rydgren 2012; Sannerstedt 2015).

\section{The growing salience of sociocultural politics and the increased politicization of the immigration issue}

The immigration issue and the various policy domains associated with it (e.g., citizenship, multiculturalism) have been the most important political issues for radical right-wing parties in Western Europe. Radical right-wing parties mobilize voters by taking a harsh stance on immigration (Ivarsflaten 2008; Rydgren 2008, 2018). The opposition to immigration and refugees among the voters of the Sweden Democrats is solid. In 2015, 93\% of the sympathizers of the Sweden Democrats agreed with the statement that it would be a good idea to reduce the number of refugees to Sweden. This should be compared to $42 \%$ of those sympathizing with the Conservative party, $29 \%$ of the Social Democratic sympathizers, and 13\% of those sympathizing with 


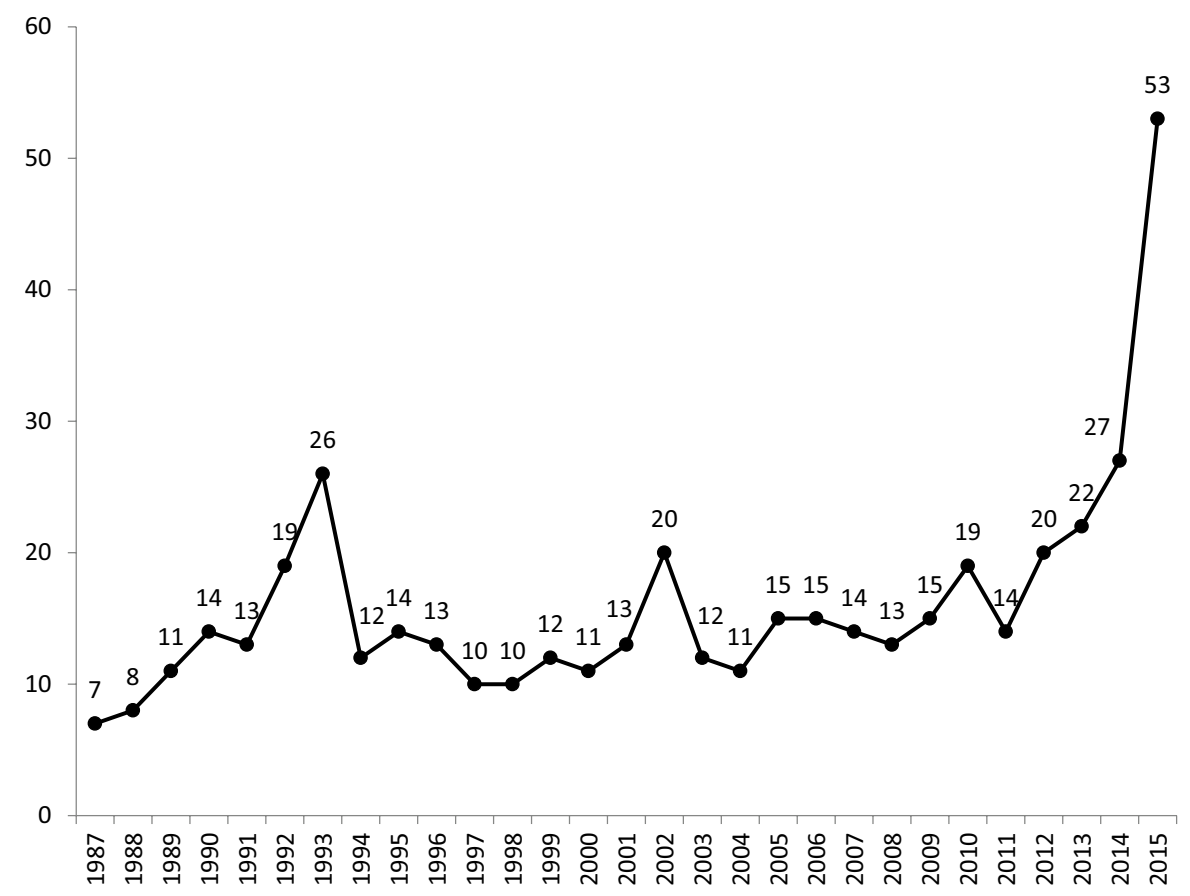

Fig. 2 The importance of the immigration issue 1987-2015 (percent). Source: Bergström and Oscarsson (2015), Demker and van der Meiden (2016)

the Green party (Demker and van der Meiden 2016). It should be noted, however, that Swedes in general have not become more negative toward refugees or immigrants to Sweden; on the contrary, general attitudes in Sweden have changed in the opposite direction. As we can see from Fig. 1, the proportion of people who think it is a good idea to reduce the number of refugees to Sweden has decreased from $65 \%$ in 1992 to $40 \%$ in 2015 .

Similarly, the proportion of the population agreeing that Sweden has too many refugees decreased from $52 \%$ in 1993 to $36 \%$ in 2009 . Likewise, the proportion opposing an immigrant marrying into the family declined from $25 \%$ in 1993 to $12 \%$ in 2009.

It should be noted that opposition to immigration was decreasing at the same time as Sweden was receiving more refugees than ever (Demker 2015).

For the immigration "issue" to impact on voters' choices, it first has to be politicized (Campbell et al. 1960). For many years, questions concerning immigration were of low importance in Swedish politics. With a few exceptions, it was largely a non-issue among the political mainstream parties until 2014 (Odmalm 2011; Widfeldt 2015). However, immigration does gain importance when a political party mobilizes around the issue, and that is also what we see in Table 1 and, even more pointedly, in Fig. 2. 


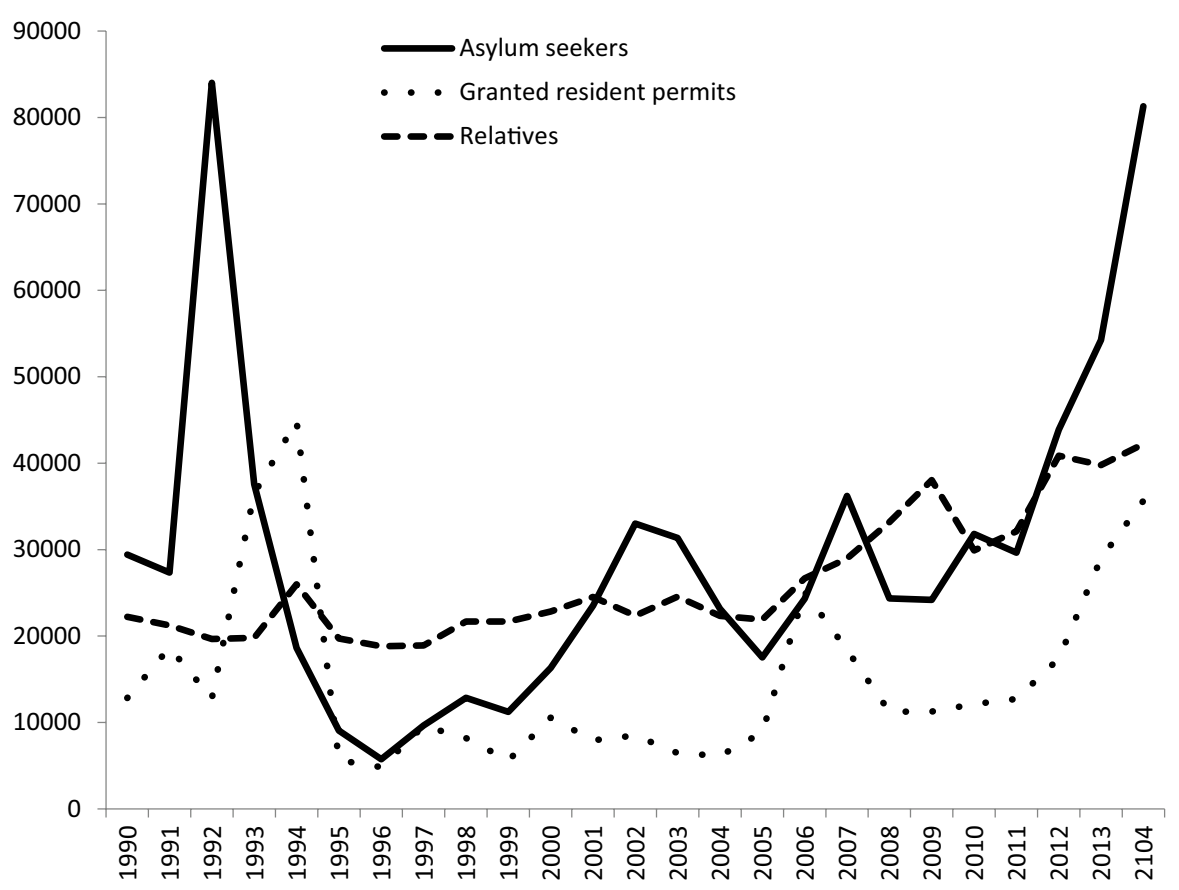

Fig. 3 Number of asylum seekers and granted resident permits for refugees and relatives 1990-2014. Source: Statistics from Swedish Migration Agency (Migrationsverket) for number of asylum seekers, granted resident permits for asylum seekers and close relatives. In addition to this are also resident permits granted for students, adopted children, labor migrants and according to the EEA treaty, but these numbers are not presented in this figure

In the national election of 1991, when the share of voters who thought that immigration and refugees were important issues when choosing a party increased sharply to $8 \%$, the right-wing populist New Democracy party won parliamentary representation. Anti-immigration was a part of their agenda, and controversial, sometimes blatantly xenophobic, statements by party representatives contributed to bring media attention to the issue. New Democracy imploded and was voted out of parliament in the 1994 election, and the immigration issue practically disappeared from the list of issues that were salient to voters. Less than two months before the 2002 election, the Liberal Party presented an immigration and integration policy package. The most discussed proposal from the Liberals was the introduction of a language test as a requirement for Swedish citizenship. Even if the proposals were arguably not designed to primarily reduce immigration, they were nevertheless interpreted as such by many voters. In the 2002 election of 2002, the Liberals almost tripled their vote, and evidence suggests that the immigration package was a part of their success (Holmberg and Oscarsson 2004; Widfeldt 2015). Although the Sweden Democrats doubled their vote share in every election since 1998, the mainstream parties did not politicize the immigration issue. Once the Sweden Democrats had won representation in parliament, however, they 
contributed to politicize immigration. The issue was also lifted high up on the agenda in the run-up to the 2014 election, when Prime Minister Fredrik Reinfeldt in a speech warned of the expected rising economic costs of immigration as a result of the influx of asylum-seekers refugees from war-torn Syria, and asked Swedish voters to "open their hearts" to the refugees. Although this speech was in line with the liberal refugee policies endorsed by the government, it also drew a lot of attention and initiated debates on the economic costs of immigration, previously absent from the (mainstream) agenda.

As shown in Fig. 3, increases in the salience of the immigration issue in 1991 and 2014 also coincided with major peaks in asylum seeking, and in 2002, it coincided with a minor peak. Other minor peaks in refugee immigration, however, such as in 2006-2007, did not coincide with increased politicization of the immigration issue. Still, we would argue that the salience of the immigration issue is particularly likely to increase in situations in which changes in real-world processes (i.e., rapid increases in refugee immigration) is combined with political articulation (i.e., when a political party mobilizes around the issue).

As Demker and Sandberg (2014) have shown, the proportion of voters holding anti-immigrant sentiments was higher among those who ranked refugee and immigration issues among the top three social problems. This means that a substantial minority of Swedish voters wanted a tighter immigration and asylum policy and considered this issue more important than most other issues. The Sweden Democrats have mobilized support among these voters.

\section{Ideological (socioeconomic) convergence of mainstream parties}

One contributing factor to the success of radical right-wing parties is the political opportunities that arise from the convergence of mainstream parties in political space (Kitschelt 1995). Convergence in political space may confuse voters about policy alternatives, and some voters may perceive mainstream parties as "being all the same," which in turn fuels discontent and distrust in political parties and politicians. Convergence may also open up niches in political space in which flank parties may mobilize (Kriesi 1999). In addition, convergence in the main political dimension, the socioeconomic dimension, may contribute to a depoliticization of that dimension by making it less engaging for the voters and the media (Schattschneider 1975; Mouffe 2005; Rydgren 2005). This creates opportunities for challengers to mobilize on alternative cleavage dimensions, including the sociocultural (Rydgren 2007; Bornschier 2010).

Developments over the past few decades have resulted in growing convergence along the socioeconomic scale, in what Mouffe (2005: 63) termed a growing "consensus of the center," but which in fact has also been a turn to the right of the whole scale (e.g., Mudge 2015). The room of maneuver for independent national economic policy has diminished as a result of the expanded European Union with its Growth and Stability Pact and the European Central Bank and the creation of independent national central banks, in which "decision-making authority is passed over to ostensibly non-partisan bodies and in which binding rules are adopted which deny 
discretion to the government of the day" (Mair 2013: 53; see also Mudge 2015). Consequently, political parties "might still compete with one another for votes, sometimes even intensively, but they came to find themselves sharing the same broad commitments in government and confining themselves to the same ever-narrowing repertoire of policy-making" (Mair 2013: 53). A politics of austerity and fiscal prudence has thus increasingly constituted a common ground for social democratic and center-right parties alike. This has been the case in Sweden as well. The deep economic crisis in Sweden in the early 1990s was the start for a shift in national economic policy. New standards in fiscal and monetary policy were imposed making economic policy more restrictive, while also diminishing the government's influence over economic policy. The Swedish Central Bank was made more independent and was tasked with stabilizing inflation at $2 \%$ annually. Hence, fighting inflation has for the past two decades been prioritized over other economic policy goals. In addition, a goal was set to balance the annual budget with a surplus of $2 \%$ of GDP, and that this surplus should be used to pay off the national debt. In addition, as Sweden prepared for EU membership in 1995, Sweden adopted the Euro Convergence Criteria, a binding plan for how to cut budget deficits and keep budgets balanced. EU membership also resulted in adoption of the Growth and Stability Pact. These changes in economic policy toward a tightening of the state budget have been implemented by both social democratic and center-right governments. Taken together, these measures have limited the room of national governments to maneuver with regard to economic policy over the past several decades and contributed to a situation in which social democratic and center-right parties have converged on economic policy.

The strategic voting-seeking behavior of the parties has also contributed to growing convergence. The distribution of voters along the socioeconomic dimension tends to approximate a bell curve, with more voters located in the center than at the poles, meaning that there are often incentives for parties to move toward the center (Downs 1957). The Social democratic parties, in particular, which have seen their traditional working-class constituencies shrink in numbers, have had strong incentives to adjust their program in order to attract middle-class marginal voters (Kitschelt 1994). This partly explains the move toward the center of social democratic parties in countries such as Germany, the UK, and Sweden since the 1990s. Simultaneously, the Conservative party in Sweden undertook a strategic makeover in the wake of the 2006 election by presenting itself as "the new working party" and by defending the Swedish welfare state. Although this shift turned out to be more discursive than factual, it signaled a rather dramatic move toward the center.

When Swedish voters are asked, the overall left-right distance between the Social Democrats and the Conservatives was perceived to be larger in the 1970s than in more recent elections (Oscarsson and Holmberg 2016). The tendency of convergence is clearly visible since the 2006 election, and in the creation of the centerright electoral coalition, the Alliance (Alliansen). ${ }^{3}$

\footnotetext{
3 When Swedish voters were asked to place political parties" position along a dimension ranging from 0 (left) to 100 (right), the Social Democrats were given 29 points and the Conservatives 89 in the election 1979. The Social Democrats were given 36, 33 and 37 points in the latest three elections in 2006, 2010 and 2014, whereas the Conservatives was given 84, 83 and 82. In the eyes of the voters, the Social Democrats moved 8 units to the right between 1979 and 2014, whereas the Conservative Party moved 7 units
} 


\section{Mainstream party responses to the Sweden democrats}

The success of radical right-wing parties partly depends on their relationship with established parties in the party system. Previous research indicates that we need to take the issue-oriented strategies of mainstream parties into account in order to understand the ways in which a radical right-wing party may mobilize voters on the immigration issue (Bale 2003; Meguid 2005; Green-Pedersen and Krogstrup 2008; Dahlström and Esaiasson 2013; Loxbo 2014). The basic notion is that mainstream parties obstruct or facilitate the growth of radical right-wing parties, depending on how they handle the immigration issue. Mainstream parties may face new competitors - such as a radical right-wing party — by using a dismissive, adversarial, or accommodative strategy (Meguid 2005). When using a dismissive strategy, mainstream parties choose not to take a position on the new party's issue, that is, the immigration issue in the case of radical right-wing parties. By avoiding the issue, mainstream parties may try both to move focus away from the immigration issue to other issues (such as economic politics), and to signal to the voters that the immigration issue is of relatively less importance. By using an adversarial strategy, mainstream parties declare opposition and distance themselves from the radical rightwing party's political program. By using an accommodative strategy, mainstream parties accommodate or coopt parts of the radical right-wing party's program. According to Meguid (2005), we should expect a decline in radical right-wing party support if mainstream parties coopt the position of the radical right-wing party, since this move is likely to draw voters away from the new challenger. According to Bale (2003), however, we should expect the opposite: a situation where mainstream parties accommodate the radical right by taking a tougher stance on immigration is likely to result in expanded political opportunities for the radical right-wing party, because it gives legitimacy to the issues it pursues. This helps the radical right-wing party to overcome a barrier of non-respectability and gain more votes (cf. Rydgren 2003).

Given these strategies, how do we understand the previous relative absence and, more recently, the increasing electoral success of radical right-wing politics in Sweden? We argue that one crucial factor has been the strategic behavior of the mainstream right-wing parties, to which the creation of the right-wing coalition the Alliance (Alliansen) in 2004 was essential. In the 2006 election, the Alliance won a majority of parliamentary seats and replaced the Social Democratic minority government. The Alliance did not place much emphasis on the immigration issue, despite a polarization on the issue among the four parties in the coalition. This was partly because the Alliance preferred internal cohesion over maximizing the party programs of the individual parties in the coalition. Had the Conservative party, for

\section{Footnote 3 (continued)}

to the left. Hence, the overall polarization between the main competitors in Sweden has decreased in the eyes of the voters (Oscarsson and Holmberg 2013; Oscarsson 2016). However, this method cannot tell us how voters define the political concepts of left and right. Despite this, it should be remembered that it is ultimately the voters' perception of reality that guides their voting behavior. 
example, drawn attention to the immigration issue in the election campaign, it would have threatened the cooperation among the Alliance parties and complicated the ability to present the Alliance as a coherent coalition. In addition, at the time, the four mainstream right-wing parties found it easier to agree on socioeconomic issues, whereas there was more disagreement on sociocultural ones, including immigration. Center and liberal parties, which usually take a more liberal stance on immigration than conservative parties, are strategically placed in the middle of the left-right dimension, which gives them the ability to make deals with the Social Democrats if they are not content with collaboration on the right. Hence, politicizing the immigration issue would make it more difficult for the mainstream right-wing parties to achieve government power (Green-Pedersen and Krogstrup 2008; Green-Pedersen and Odmalm 2008).

After the 2010 election, when the Sweden Democrats won parliamentary representation, the Alliance lost its majority but continued in government. Up until 2010, partly for coalition-strategic reasons, the mainstream right-wing parties used a dismissive strategy vis-à-vis the Sweden Democrats. This was successful for a long time and likely one of the reasons why the electoral breakthrough of Sweden Democrats took so long (Rydgren 2010; Dahlström and Esaiasson 2013). As a minority government after the election of 2010, the Alliance was forced to seek external support to get its policies through parliament. Partly in order to prevent the Sweden Democrats from getting influence over migration policy, the Alliance and the Green party (Miljöpartiet) struck a deal in 2011. Since the Green party was one of the most socioculturally liberal parties, this agreement moved immigration policy in a more liberal direction. As a result, the mainstream parties converged on the immigration issue. This may have benefited the Sweden Democrats for at least two reasons (cf. Loxbo 2014): First, liberalization of immigration policy contributed to the politicization of immigration and put the issue higher on the agenda. Second, the increased convergence on the issue gave the Sweden Democrats a monopoly over offering a more restrictive immigration policy program. Moreover, this policy change was coupled with a clear adversarial strategy toward the Sweden Democrats, and it is an open question whether or not this strategy benefited the Sweden Democrats. On the one hand, it provided the party with an opportunity to present itself as martyrs being unjustly ostracized, and it is reasonable to assume that the party found greater sympathy for this claim once it was represented in parliament-which may have increased the expectations among its potential supporters that other parties should pay attention to the Sweden Democrats. On the other hand, the Sweden Democrats may have suffered from a loss of legitimacy caused by the mainstream parties' adversarial strategy, even though the party was now arguably less sensitive to this than before, since the party was now represented in parliament, which in itself may have a legitimizing effect.

\section{Sweden democrats: being seen as an increasingly legitimate party?}

The Sweden Democrats was founded in 1988 as a successor to The Sweden party (Sverigepartiet), which in turn was founded in 1986 as a result of the merging of 
the Progress party and the racist and far right group Keep Sweden Swedish (Bevara Sverige Svenskt) (Lodenius and Wikström 1997: 124; Rydgren 2006). Hence, unlike its sister parties in Denmark and Norway, the Sweden Democrats originated from an extreme right-wing milieu, as a result of which it was long viewed as illegitimate by a large segment of the voters, as well as by the mainstream parties. Hence, one of the main reasons why Sweden lacked an electorally successful radical rightwing party until the 2010 election was that the Sweden Democrats failed to present a façade that was respectable enough (Rydgren 2002).

In fact, the Sweden Democrats ambivalent relationship to neo-Nazis and other openly right-wing extremists has been a recurrent problem for the party. During the first half of the 1990s, the boundaries were blurred, and around the mid-1990s, the new party leadership banned political uniforms at Sweden Democrat demonstrations. Nonetheless, it was still not uncommon to find Sweden Democrat activists, who had previous or current connections to neo-Nazi environments, even in relatively prominent positions. Since then the party has increasingly tried to distance itself from the extra parliamentary extreme right in order to present a more respectable façade to the voters. This work was facilitated when one of the party's hard line factions left the party to form the National Democrats, and when the Sweden Democrats managed to recruit the Conservative party MP Sten Andersson to the party ahead of elections in 2002; something which signaled increased legitimacy. Work to present a more respectable façade intensified ever since Jimmy Åkesson became party leader in 2005, which may have contributed to the party's relative success in the 2006 election, in which the party managed to increase its voter share from $1.4 \%$ to almost $3 \%$ and gained more than 250 seats on different local councils (Rydgren 2010). In 2010, the Sweden Democrats entered parliament with 5.7\% of the votes, in 2011 the party officially changed its designation from nationalist to social conservative, and in 2012 the party introduced what it called "zero tolerance for racism," which resulted in numerous expulsions of party members who had publicly expressed opinions deemed too racist (Widfeldt 2015). One may argue that these expulsions were primarily cosmetic and designed to signal to the voters that the party had a serious desire to rid itself of its too politically extreme past (obvious violations of this rule by more centrally placed Sweden Democrats did not lead to expulsion), but it likely helped to destigmatize the party in the eyes of many voters.

To understand the processes in which radical right-wing parties gain increased legitimacy, we need to consider mass media (Andersson 2010; Ellinas 2010). Media coverage is important not only because it contributes to the visibility of the party, which is crucial for new parties lacking economic resources, but also because it may contribute to increased legitimacy and respectability as well as name recognition (Ellinas 2010).

As shown in Fig. 4, the media attention devoted to the Sweden Democrats has increased substantially over the past two decades. In the run-up to the 2010 election, for example, the Sweden Democrats received more media publicity than some established parties, such as the Christian Democrats and the Left party. This was immensely important for a small party lacking economic resources, even though much of the coverage was negative. Despite efforts by the Sweden Democrats to present a more respectable façade, the party still struggles with scandals and controversial statements 


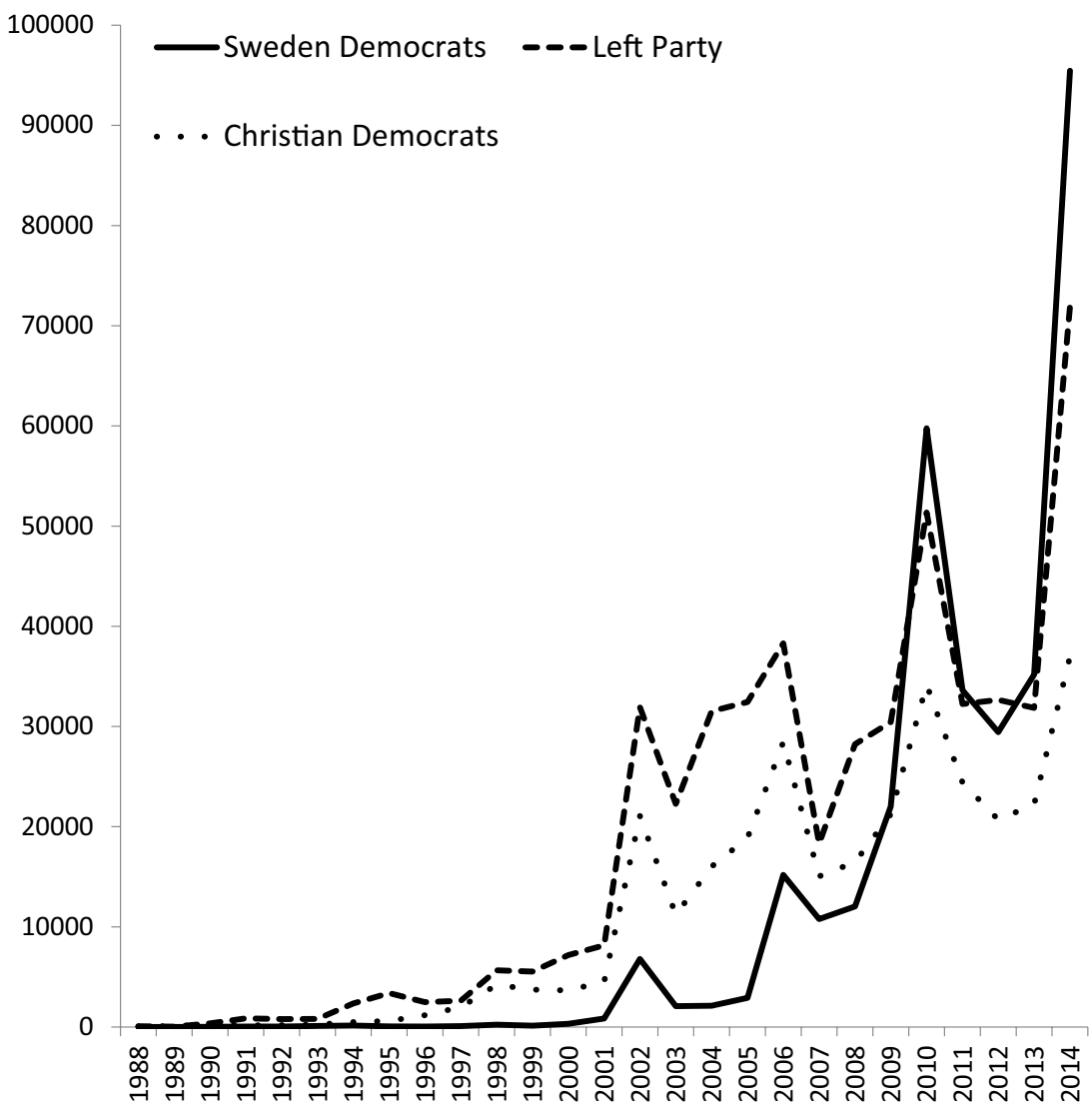

Fig. 4 Number of times the Sweden democrats, the left party and the Christian democrats are mentioned in Swedish media 1988-2014. Source: The Swedish media archive (Mediearkivet), the number of times keyword "Sverigedemokraterna", "Vänsterpartiet" and "Kristdemokraterna" is mentioned in Swedish printed press and web 1988-2014

from party representatives. The so-called iron pipe-scandal, which occurred in 2010, only received media attention in 2012 when a videotape was released showing two MPs and one highly placed party representative from the Sweden Democrats verbally attacking with racist and sexist epithets, a woman on the street and a Swedish comedian coming to her aid. One of the Sweden Democrats was shown shoving a woman into the side of a car, and they armed themselves with iron pipes. However, despite this and other controversies that received considerable media attention, support for the Sweden Democrats was not affected significantly. There is some evidence that radical right-wing parties are less sensitive to negative publicity, compared to mainstream parties (Ellinas 2010). One potential explanation is that the mass media are seen as a part of "the political establishment," which is believed to be conspiring against the radical right (Andersson 2010). There is also a widespread distrust of the media among supporters of the Sweden Democrats. Among Sweden Democrat supporters, for example, 93\% believe that Swedish media does not tell the truth about immigration (Demker 
2015). ${ }^{4}$ In addition, over the past decade alternative, online-based news media have become increasingly important, and the Sweden Democrats have been successful in, directly or indirectly, launching such media propagating for its political program. The web-based news platform Avpixlat, for example, reached between 200,000 and 300,000 unique visitors per week (Krzyzanowski et al. 2016).

\section{Conclusion}

This article began with the observation that for a long time Sweden differed from other countries in Western Europe in that it lacked a radical right-wing party in parliament-a situation that changed in 2010. In the article, we have offered potential explanations for the relatively late emergence and electoral breakthrough of radical right-wing politics in Sweden. First, until recently, enduring class loyalties in Sweden worked against radical rightwing mobilization in Sweden. Working-class voters identified strongly with their social class and the Social Democratic party, which tended to make them largely unavailable for radical right-wing mobilization. However, declining class politics over the past decades has transformed the political landscape. Second, the salience of the socioeconomic dimension in Sweden used to work as a shield against attempts to mobilize on issues belonging to other political dimensions (such as sociocultural ones). However, the sociocultural dimension and, most importantly, the immigration issue, have gained in salience over the last decade. This has benefited the Sweden Democrats. Third, the increased convergence on the socioeconomic dimension, with growing consensus among the mainstream parties, has contributed both to the depoliticization of socioeconomic politics and to increased resonance for the Sweden Democrats' claim that there are no differences between mainstream parties ('they are all the same"). Fourth, the leading radical right-wing party, the Sweden Democrats, has been working hard to distance itself from its past and cultivate a more respectable façade, a strategy that seems to have been relatively successful in the eyes of many voters.

Our study thus points to the need to combine demand-side and supply-side factors (Rydgren 2007; Mudde 2007), while also taking the interplay between structural processes and the strategic behavior of political actors into account. It also highlights the importance of separating factors explaining the electoral breakthrough of radical rightwing parties from factors explaining the further electoral growth of the same parties. For example, the Sweden Democrats managed to win representation to Swedish parliament in 2010 despite the fact that the immigration issue was still of low salience. Because the Sweden Democrats were represented in parliament after 2010, however, the dynamics of the political field (Bourdieu 2000) changed, which contributed to increased politicization of the immigration issue- which in turn partly explains why the Sweden Democrats were able to double their vote between the 2010 and 2014 elections.

Open Access This article is distributed under the terms of the Creative Commons Attribution 4.0 International License (http://creativecommons.org/licenses/by/4.0/), which permits unrestricted use, distribution, and reproduction in any medium, provided you give appropriate credit to the original author(s) and the source, provide a link to the Creative Commons license, and indicate if changes were made.

${ }^{4}$ This should be compared to $60 \%$ among the general population. 


\section{References}

Andersen, J.G., and T. Bjørklund. 1990. Structural Changes and New Cleavages: The Progress Parties in Denmark and Norway. Acta Sociologica 33(3): 195-217.

Andersson, C. 2010. Populism och journalistik-stadigt sällskap eller tillfällig bekantskap? Statsvetenskaplig tidskrift 112(3): 271-287.

Bale, T. 2003. Cinderella and Her Ugly Sisters: The Mainstream and Extreme Right in Europe's Bipolarising Party Systems. West European Politics 26(3): 67-90.

Bergström, A., and H. Oscarsson. 2015. Svenska Trender 1986-2014. Göteborg: SOM-institutet vid Göteborgs universitet.

Betz, H.-G. 1994. Radical Right-Wing Populism in Western Europe. New York: St. Martins Press.

Bornschier, S. 2010. The New Cultural Divide and the Two-Dimensional Political Space in Western Europe. West European Politics 33(3): 419-444.

Bourdieu, P. 2000. Propos sur the champ politique. Lyon: Presses Universitaires de Lyon.

Campbell, A., P.E. Converse, W.E. Miller, and D.E. Stokes. 1960. The American Voter. New York: John Wiley.

Clark, T.N., and S.M. Lipset (eds.). 2001. The Breakdown of Class Politics: A Debate on Post-Industrial Stratification. Baltimore: Johns Hopkins University Press.

Dahlström, C., and P. Esaiasson. 2013. The Immigration Issue and Anti-immigrant Party Success in Sweden 1970-2006: A Deviant Case Analysis. Party Politics 19(2): 343-364.

Demker, M. 2015. Mobilisering kring migration förändrar det Svenska partisystemet. In Fragment: SOM-undersökningen 2014, ed. B. Johansson, M. Oskarson, H. Oscarsson, and A. Bergström. SOM-institutet: Göteborg.

Demker, M., and L. Sandberg. 2014. Starkare oro för främlingsfientlighet än för invandring. In Mittfåra and marginal: SOM-undersökningen 2013, ed. H. Oscarsson and A. Bergström. Göteborg: SOM-institutet.

Demker, M., and S. van der Meiden. 2016. Allt starkare polarisering och allt lägre flyktingmotstånd. In Ekvilibrium: SOM-undersökningen 2015, ed. J. Ohlsson, H. Oscarsson and M. Solevid. SOMinsitutet: Göteborg.

Downs, A. 1957. An Economic Theory of Democracy. New York: Harper Collins.

Ellinas, A.A. 2010. The Media and the Far Right in Western Europe: Playing the Nationalist Card. New York: Cambridge University Press.

Evans, G. (ed.). 1999. The End of Class Politics? Class Voting in Comparative Context. Oxford: Oxford University Press.

Evans, G., and J. Tilley. 2012a. How Parties Shape Class Politics: Explaining the Decline of the Class Basis of Party Support. British Journal of Political Science 42: 137-161.

Evans, G., and J. Tilley. 2012b. The Depoliticization of Inequality and Redistribution: Explaining the Decline of Class Voting. The Journal of Politics 74(4): 963-976.

Green-Pedersen, C., and J. Krogstrup. 2008. Immigration as a Political Issue in Denmark and Sweden. European Journal of Political Research 47: 610-634.

Green-Pedersen, C., and P. Odmalm. 2008. Going Different Ways? Right-Wing Parties and the Immigrant Issue in Denmark and Sweden. Journal of European Public Policy 15(3): 367-381.

Holmberg, S., and H. Oscarsson. 2004. Väljare: Svenskt väljarbeteende under 50 år. Stockholm: Norstedts Juridik.

Ivarsflaten, E. 2008. What Unites Right-Wing Populists in Western Europe? Reexamining Grievance Mobilization Models in Seven Successful Cases. Comparative Political Studies 41: 3-23.

Jansen, G., G. Evans, and N.D.D. Graad. 2012. Class-Voting and Left-Right Party Positions: A Comparative Study of 15 Western Democracies, 1960-2005. Social Science Research 42: 376-400.

Kitschelt, H. 1994. The Transformation of European Social Democracy. Cambridge: Cambridge University Press.

Kitschelt, H. 1995. The Radical Right in Western Europe: A Comparative Analysis. Ann Arbor: University of Michigan Press.

Kitschelt, H. 2012. Social Class and the Radical Right: Conceptualizing Political Preference Formation and Partisan Choice. In Class Politics and the Radical Right, ed. J. Rydgren. London: Routledge.

Kriesi, H. 1999. Movements of the Left, Movements of the Right: Putting the Mobilization of Two New Types of Social Movement into Political Context. In Continuity and Change in 
Contemporary Capitalism, ed. H. Kitschelt, P. Lange, G. Marks, and J.D. Stephens. Cambridge: Cambridge University Press.

Kriesi, H., R. Koopmans, J.W. Duyvendak, and M.G. Giugni. 1995. New Social Movements in Western Europe: A Comparative Analysis. Minneapolis, MN: University of Minnesota Press.

Krzyzanowski, M., P. Ledin, and J. Rydgren. 2016. Swedish Socio-Cultural Politics, Discursive Shifts, and the Refugee Crisis. Paper Presented at the Mediatisation and Politicisation of Refugee Crisis in Europe Workshop, European University Institute, Florence, 27 April 2016.

Larsson, B. 2015. Facklig anslutning år 2015. Facklig anslutning bland anställda efter klass och kön år 1990-2015. Arbetslivsenheten, LO.

Lodenius, A., and P. Wikström. 1997. Vit makt och blågula drömmar: rasism och nazism $i$ dagens Sverige. Stockholm: Natur och kultur.

Loxbo, K. 2014. Voters' Perceptions of Policy Convergence and the Short-term Opportunities of Antiimmigrant Parties: Examples from Sweden. Scandinavian Political Studies 37: 239-262.

Mair, P. 2013. Ruling the Void: The Hollowing of Western Democracy. London: Verso.

Meguid, B.M. 2005. Competition Between Unequals: The Role of Mainstream Party Strategy in Niche Party Success. The American Political Science Review 99(3): 347-359.

Mouffe, C. 2005. On the Political. London: Routledge.

Mudde, C. 2007. Populist Radical Right Parties in Europe. Cambridge: Cambridge University Press.

Mudge, S.L. 2015. Explaining Political Tunnel Vision: Politics and Economics in Crisis-Ridden Europe, Then and Now. European Journal of Sociology 56(1): 63-91.

Nieuwbeerta, P., and D. De Graaf. 1999. Traditional Class Voting in Twenty Postwar Societies. In The End of Class Politics? Class Voting in Comparative Context, ed. G. Evans. New York: Oxford University Press.

Odmalm, P. 2011. Political Parties and 'The Immigration Issue': Issue Ownership in Swedish Parliamentary Elections 1991-2010. West European Politics 34(5): 1070-1091.

Oesch, D. 2008. Explaining Worker's Support for Right-Wing Populist Parties in Western Europe: Evidence from Austria, Belgium, France, Norway, and Switzerland. International Political Science Review 29(3): 349-373.

Oscarsson, H., and S. Holmberg. 2013. Nya svenska väljare. Stockholm: Norstedts juridik.

Oscarsson, H. 2016. Floating Voters. Statistics Sweden, Democracy statistics report no 21.

Oscarsson, H., and S. Holmberg. 2016. Issue Voting Structured by Left-Right Ideology. In The Oxford Handbook of Swedish Politics, ed. J. Pierre. Oxford: Oxford University Press.

Oskarson, M. 2005. Social Structure and Party Choice. In The European Voter. A Comparative Study of Modern Democracies, ed. J. Thomassen. Oxford: Oxford University Press.

Oskarson, M., and M. Demker. 2013. Another Kind of Class Voting: The Working-Class Sympathy for Sweden Democrats. In Class Politics and the Radical Right, ed. J. Rydgren. London: Routledge.

Rydgren, J. 2002. Radical Right Populism in Sweden: Still a Failure, But for How Long? Scandinavian Political Studies 25(1): 27-56.

Rydgren, J. 2003. The Populist Challenge: Political Protest and Ethno-Nationalist Mobilization in France. New York: Berghahn.

Rydgren, J. 2005. Is Extreme Right-Wing Populism Contagious? Explaining the Emergence of a New Party Family. European Journal of Political Research 44: 413-437.

Rydgren, J. 2006. From Tax Populism to Ethnic Nationalism: Radical Right-Wing Populism in Sweden. New York: Berghahn Books.

Rydgren, J. 2007. The Sociology of the Radical Right. Annual Review of Sociology 33: 241-262.

Rydgren, J. 2008. Immigration Sceptics, Xenophobes or Racists? Radical Right-Wing Voting in Six West European Countries. European Journal of Political Research 47: 737-765.

Rydgren, J. 2010. Radical Right-Wing Populism in Denmark and Sweden: Explaining Party System Change and Stability. The SAIS Review of International Affairs 30(1): 57-71.

Rydgren, J. (ed.). 2012. Class Politics and the Radical Right. London: Routledge.

Rydgren, J. (ed.). 2018. The Oxford Handbook of the Radical Right. Oxford: Oxford University Press.

Rydgren, J., and S. van der Meiden. 2016. Sweden, Now a Country Like All the Others? The Radical Right and the End of Swedish exceptionalism. The Department of Sociology Working Paper Series 25/2016. Stockholm University.

Sannerstedt, A. 2015. Hur extrema är Sverigedemokraterna? In Fragment, ed. A. Bergström, B. Johansson, H. Oscarsson, and M. Oskarson. Gothenburg: Göteborgs Universitet: SOM-institutet.

SCB. 2015. Statistics Sweden, the Party Preference Survey in November 2015. 
Schattschneider, E.E. 1975. The Semisovereign People: A Realist's View of Democarcy in America. London: Wadsworth.

Widfeldt, A. 2015. Extreme Right Parties in Scandinavia. London: Routledge.

Jens Rydgren is Professor of Sociology at Stockholm University. He is working within the fields of political sociology and ethnic relations, and his work has appeared in leading journals such as the American Journal of Sociology, Annual Review of Sociology, and European Journal of Political Research. He has been the author and editor of several books, most recently The Oxford Handbook of the Radical Right (ed., Oxford University Press, 2018) and Class Politics and the Radical Right (ed., Routledge, 2013).

Sara van der Meiden is Associate Researcher at the Department of Sociology, Stockholm University. 